\title{
E-publishingdevelopmentanddhangesinthe scholartycommumicationsystem
}

\section{PatriciaNascimentoSouto}

Information, Technology and Society Research Group Department of Information Science Loughborough University.

E-mail: patriciacnascimento@gmail.com

\begin{abstract}
New and alternative scientific publishing business models is a reality driven mostly by the information and communication technologies, by the movements towards the recovery of control of the scientific communication activities by the academic community, and by the open access approaches.

The hybrid business model, mixing open and toll-access is a reality and they will probably co-exist with respective trade-offs. This essay discusses the changes driven by the epublishing and the impacts on the scholarly communication system stakeholders' interrelationships (publishers-researchers, publishers-libraries and publishers-users interrelationships), and the changes on the scientific publishing business models, followed by a discussion of possible evolving business models. Whatever the model which evolves and dominates, a huge cultural change in authors' and institutions publishing practices will be necessary in order to make the open access happen and to consolidate the right business models for the traditional publishers. External changes such as policies, rewarding systems and institutions mandates should also happen in order to sustain the whole changing scenario.
\end{abstract}

Keywords

E-publishing. Open access. Scholarly communication. Scientific communication. Business models.

Desenvolvimento das publicações eletrônicas e as mudanças no sistema de comunicação científica

\section{Resumo}

Os novos e alternativos modelos de negócio no sistema de publicação científica no formato digital compõem uma realidade conduzida, na sua maior parte, pelas tecnologias de informação e de comunicação, pelos movimentos para a recuperação do controle das atividades de comunicação científica pela própria comunidade acadêmica e pelas abordagens de acesso aberto ou livre (open access). O modelo de negócio híbrido, o qual combina o acesso aberto e o acesso restrito / pago (toll-access), é um modelo que provavelmente coexistirá. Esse artigo discute as mudanças que as publicações eletrônicas geraram no interrelacionamento entre os atores na cadeia de comunicação científica (interrelacionamento entre editores-pesquisadores, editores-bibliotecas e editores-usuários) e também os impactos gerados nos modelos de negócio no sistema de publicação científica. Em seguida, discutem-se os modelos de negócio que possivelmente podem evoluir e coexistir. Qualquer que seja o modelo de negócios que predomine, será essencial que ocorra profunda mudança cultural nos autores e nas práticas de publicação das instituições, de forma a permitir que o modelo de acesso aberto (ou acesso livre) desenvolva-se e também a possibilitar a consolidação um modelo de negócio adequado e viável para os publicadores tradicionais. Igualmente essencial e visando a sustentar esse cenário em contínua evolução, é a necessidade de mudanças em aspectos externos ao processo de publicação, tais como nas políticas, nos sistemas de recompensa e nas regras institucionais relacionadas 'a comunicação e publicação científicas.

\section{Palavras-chave}

Publicações eletrônicas. Publicações digitais. Comunicação científica. Modelos de negócio. Acesso aberto. Acesso livre.

\section{INTRODUCTION}

E-publishinghasundoubtedlyaffectedall stakeholders' interrelationships in the scholarly publishing value chain* pressuringpublishersintheirvaluedelivery tolibranies and users, ithasenabledapowerful function forlibraries andithaschallengedmarketforcesandactors which have orchestrated howsciencehas been communicated until recently. Crow (2002, p.20) emphasised that each stakeholder involved in the system of scholarly communication has been affected by the digital publishingtechnologies. Likewise, new and alternative business models haveemerged in order to copewith the challenging open access models and the disaggregating potential of e-publishing.

On top of these, themovements towards therecovery of control of the scientific communication activities by the academic community can be seen, as well as a reaction to the publishers' economic ${ }^{* *}$ and operational models, to thecopyright practices and to theeffects of the publishers' monopolistic performance on institutionsandlibraries.

Within thisscenario, diversechanges on thestakeholders' interrelationshipsandonthebusinessmodelsinthescholanly communication system have been primarilylead by the impacts of e-publishing on this system. Thesechanges includethefollowing: (a) thelowering of entry barriers in the supply side, (b) theemergence of thealternative open access (OA) models, (c) the potential for disaggregation of publishingactivities, and (d) thethreat of productsand servicessubstitution represented byOA alternatives (figura 1).

The whole changing scenario outlined above has promoted an increased the participation of academein theprocesses of scientific communication and it hasalso injected somecompetition into themonopolisticnature

${ }^{*}$ Value chain is the set of activities performed in order to run a business. They are divided in technological and economic activities. These activities are called "value activities" (Porter \&Millar, 1985, p.3).

${ }_{* *}^{*}$ In the last 30 years, the prices of scientific journals have been steadily increasing. Between 1975 and 1995, they increased 200\%300\%beyond inflation (Dewatripontetal., 2006, p.5). 
of the scholarship industry. Coordinated action and effort to change the status quo havearisen, including efforts to change therules and forces of that govern the logic of the market. Underlyingthis, e-publishing has enabled access models that actually privilegethewider socialising of science, supporting inclusion of institutionsandacademicsin disseminating theirown intellectual creation.

Within this context, this essay discusses the changes on thestakeholders' interrelationshipand on thebusiness models in thescholarlycommunication system, which were driven bye-publishing. Following this discussion, possibleevolvingbusinessmodelsarealso presented.

\section{IMPACTSOFE-PUBLISHING}

\section{Impadsonstakeholders'interrelationships}

New entrants in the supply side of the scholarly communication system wereenabled by theOA, strongly challengingtherelationshipsamongpublishers, libraries and authors. Competitiveness has been gradually injected to the market, sincethenewentrantsarenow performingsome of the scientificpublishingfunctions, such as registering, archivingand dissemination 11 . The onlineresources promotea way for authors to increase theirwork dissemination and its consequent usageand impact (Harnad, 2005). Additionally, the academic actors have been realising that they can assume the performance of some processes in the scholarly communication system, for which they have been actuallyresponsibleforyears (Crow, 2002, pp. 7-9).

\section{Impactsonthepublishers-researchers(asauthors) interrelationships}

The major e-publishing impacts on the publisherresearcher interrelationship havebeen observed on the controversial issues aboutcopyright ownership and on theinclusion ofresearchersas thedisseminatorsof their own workin any stage of its development.

In an OAmodel, thecopyright ownershipis required to remain with authors or with the institution, which licensespecificrights to publishers. Aoconding to Crow (2002, pp. 21-22) theauthors' retention of thecopyright and the retention of theright to publish copies of their articles in OA journals or in institutional repositories (IRs) areessential elements of thechanges which have beingoocurringin thescholarly publishingsystem.
FIGURE1

Changesenabledandpromotedbye-publishingwhich affectedthestakeholders internelationshipsandbusiness modek.

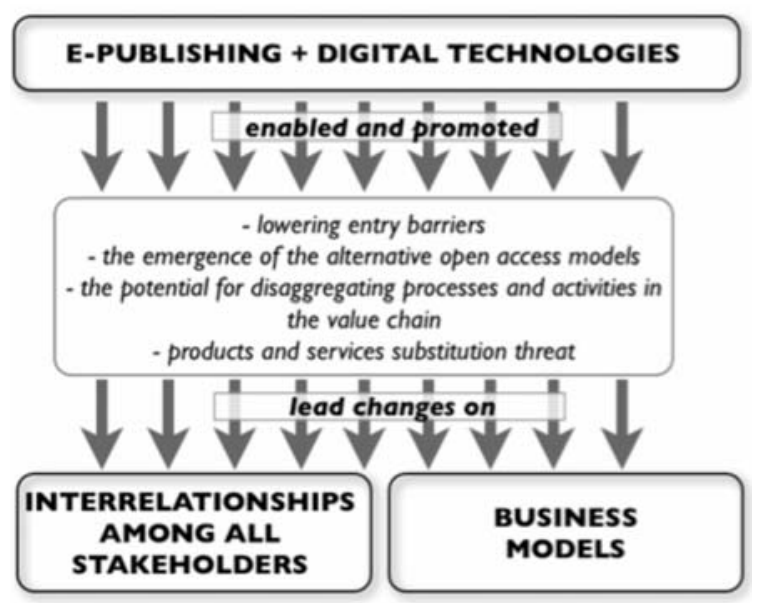

Currently, authors arestill dependent on publishers for reusing their own material and for publishing it on the open access models. The authors' recovering of their copyright ownershipaffects this currentrelationship of dependence, becauseinstead of assigningtotal oopyright to publishers, authors can assign only specific rights to publishers, usinglicenses likethe Creative Commons. Actually, publishers do not need copyright transfer agreements either to publish or to exploit the article commencially (Gaad etal., 2003, p.266, Hoorn, 2005, p.63). Therefore, the returning of the copyright ownership to authors' reduces their dependence on publishers freeing them to the dissemination and exploitation of their own research workfor educational and commencial purposes.

In addition, theOA strategies haveenabled researchers and institutions to become disseminators of their own intellectual production and to breach the distribution channel exclusivity owned by publishers. The dissemination of their own intellectual production can bemadein any stage of its developmentas pre-refereed (pre-print) and refereed published articles (post-print). This has promoted the exchanging of ideas and comments about a work, its informal quality certification, and mainly its wider and free of charge dissemination. These new practices affect the relationshippublishers-researchers, sinceresearchersas authors start demandingthe possibility to self-archive pre-prints of their work withoutaffecting thepossibility havingit published further. Additionally, theuse of OA 
journals as a complement to traditional publishers"* work can be identified by the growing participation of authors in OA journals, rising from $11 \%$ (in J anuary 2004) to 29\% (in J uly 2005) (Rowlands \&Nicholas, 2006, p.44).

Within this scenario, the growing of free online scientific content which is resulted from authors' dissemination can pressure traditional publishers to refocus their offerings and to offer morevalued services beyond thesinglecontent delivery.

\section{Impacts on the publishers-libraries interrelationships}

Thepublisher-libraryinterrelationshiphasbeen affected because with the IRs, libraries are becoming actively involved and heavily responsiblefor the dissemination and archiving of the research outputs of theirinstitution. All thesechanges haveincreased librarians' visibilityand promotedamore strategicimportancefor theminsidetheinstitution.

With the growth in adoption and use of IRs (figura 2) libraries havealeadingrolein themanagement of IRs sincetheyare responsiblefororganising, archivingand disseminatingtheintellectual creation of theinstitution. It should beremembered that peer-reviewed archives with an efficient search engineperform thefunctions of journals(WelloomeTrust, 2004, p.24). Consequently, the newposition of libraries threats publishers, sincethey can publish their own scientific workand intermediate theworkfrom other universities.

Within this newcontext, librarians acquire newroles such as facilitators of some of the attitudinal changes required to support theIRresults, and as pointed outby J ohnson (2004) and Bosc \& Harnad (2005, p.99), librariansacquire theroleof promoters of OAjournals and self-archiving, includingOA resources and services in the library gateways. Additionally, libraries will have moreknowledgein relation to the users than publishers will do, becausethey will continueto bethemain gateway for the wholedistributed scientific content access.

Thepublishers-librariesinterrelationshiphasalso been affected by users' article-based consumption behaviour. Waltham (2003, p. 10) has pointed out that "readersare

${ }^{*}$ Traditional publishers are considered those who are based on subscription-based-libraries-pay. interested in smallerunits, individual articles" and that they purchase information in smaller units than those in print-based market. This change demands that the negotiation between librariesand publishers be based on articles, rather than onlargerpackages ofinformation, makinglibraries budgetmore flexibly managed. Thus, thepublishers-librariesinterrelationshipshould beoome more flexible and be governed by lower and more manageablecosts, becausetheexchangeunitwill bebased on articles and on the effective combination of articles that can match users' needs and libraries budgets. The artide-based consumption will also demand newservices (e.g. search tools, citationlinking, singleinterface) from publishersand libraries, influencing on thepractice ofa morecooperativeinterrelationship between both.

\section{Impadsonthepublishers-usersinterrelationships}

Thepublisher-user interrelationshiphas bøen affected by theincreased usage of digital scientificinformationand user's article-based consumption behaviour. Consequently, users demand convenient access to qualified scientific information and increasingly sophisticated digital services to navigatethrough and usethisinformation. Moreover, users want "to select and acoess distilledand well-written arguments" usinga common interface without having to access different interfacesfrom differentsystems and publishersin order to accesscontent(Waltham, 2003, p.8).

Asan answer to thesechanges, thescholarlypublishing hasgraduallybecomemoreservioes-oriented, supporting expectations of users in findingqualified information, 
and the required accessibility, searchability and navigability for scientific information. Thus, sophisticated services have been developed to enable searching across databases* (Houghton etal., 2004, p.236), to make correlation between complementaryinformation, toimprove navigability through the content interconnecting subjects, documents, citations, authors orkeywords, todeliver summaries, togiveoff-campusacoess, and to also make hyperlinks to referenced material, dynamic commentaries and social filtering (MacKie-Mason et al., 1999, MacKie-Mason \&Riveros, 2000, pp. 211-212).

Thearticles-based consumption of users requires theunbundling of journal componentsand the rebundlingin different, customised and customisable packages. On top of this, there is the lowimportance that journals brand can have to thenewstudents and researchers generation, which will valuearticles, their authors and content more than the journal in which they were published. Houghton (2004, p.181) has pointed out that journal databases availability and the practice of searchingbyauthor or keywords haveshown that users havebeen seekingfor articles apart from the journal, evidencing that the journal itself has less importancetothem.

Within this context, publishers will haveto support the availability of high quality and carefully sorted information (Waltham, 2003, p.8) and digital services. However, firstly they need to know their customers' better. Waltham (2003, p.13) have emphasised that publishers should knowusers andinteract with themin order to discover what they want and valueand how theyreally usetheonlineinformation. This will demand to keep closer to libraries and mainly, to make a substantial shift from publishers' product-centred focus to a morecustomer-centred perspective.

\section{Impadsonbusinessmodets}

Afinancial perspective ${ }^{* *}$ of businessmodelswas adopted in thisstudyto outlinethemajorimpactsofe-publishing

\footnotetext{
* Specialized search tools that harvest metadata with a focus on scientific information such as Google Scholar, Yahoo, OAIster and Scirus.

** The financial perspective encompasses answers that describe how money or how the financial sustainability is expected to be made.
}

(Table1) and to guidethesubsequentanalysisof someof thesebusiness models. Theframework fore-business models which wasproposed by Clarke(2004) wasused to basistheanalysis.

Thechangesproduoed bye-publishingon thebusiness models in the scholarly communication system have been primarily related to the need for adapting to the following: (a) theincreasing onlinedelivery of scientific information, (b) the emergence of theopen access, and (c) thepotential for disaggregatingpublishingactivities. All thesechanges are discussed in thefollowingitems.

\section{Adaptingbusinessmodklstoanincreasingdigitalwordd}

The revenue streams have being changing with the online delivery of scientific information because the sellingunit has becamearticlesand themarginal costs of performing this delivery is near zero, demanding a different pricing strategy based on value perceived by users, rather than be based on costs. Chuang \&Sirbu (2000, p. 138) pointed out that theaggregation of articles in journals is a strategy that works in the paper-based market because of theeconomies of scale. Reinforcing theincreaseofan article-basedmarket, Waltham(2003, p.11) pointed out that print-only materials will not be part of the reality for a generation of students and researchers that practically was born or has much experience with digital technologies to access information.

In addition, Chuang \& Sirbu (2000, pp. 140-161) demonstrated that theoffering of bothindividual articles 
andjournal subscriptions (i.e. themixedbundling) isthe dominantstrategyand itcanincreasepublisher surplus. Theanalysis developed by theauthors suggested thata scholarlypublisher "should expand its onlineproducts by offeringto includeunbundled articles in addition to traditional subscriptions".

Therefore, the increasing delivery of scientific information on adigital formataffectspricingand selling practices, demanding a publishers' review on their strategies and a stronger partnership with libraries in onder to makemoreinformation-based decisions. The printjournals enabled great deals for publishers, and guaranteed their business revenue for the period of contracts, butnow, in an article-based digital economy this guaranteeis weakened.

\section{Adaptingbusinessmodelstotheemengenceofopen access}

E-publishing and OA models haveenabled lower costs for disseminating researchers' work, breaching the bargaining power originated from the publishers' exclusivity in this dissemination. E-publishingand OA models havealso challenged publishers' comfortable pricing position, which is only possible in a monopolistic-basismarket. Thereport developed by the WelloomeTrust (2004, p. 19) has pointed out thisissue asfollows:

“.. question facingpublishersisnot whetherto offer open acoess ornot, buthowto position theirjournals so that they areableto continueto playanimportant part in a world in which open access, through open archives and very cheap or freedocument delivery, is thenorm".

Within this context, the businessmodels varyacoording to the OA strategy as shown in the followingitems.

\section{(a) The[full] OAJournals}

OAjournalsmakepeer-reviewed contentfreelyavailable toallusers, usingother sources offunding tocover thecosts. In theirfundingmodel users can download, copy, read, distributeand printresearch outputsfree of charge. Their costsarefunded by thefollowing sources of inoome:

(i) Membershipfees- thismodelisenoounteredinSPARC, which has over 300 research institutions, libraries and organisationsin theUnited Statesand 100 institutions in 14 European countries which are considered as members (Lustria\&Case, 2005, p.238). (ii) Author-paysmodel - underacoeptanceof thearticle, the author's institution, research grant or funding organisation pays a fee in order to finance the publication. Seventeen percent of journals listed by DOAJ areauthor-pays (Regazzi, 2004, p.276). Thisfee covers the peer review, production and the online publishing processes(Cox, 2004, p.65). Currentauthorpays models havetheir costsfunded only by acceptedarticles-authors and they are insufficient to cover publishing costs. Most of the costs are fix (Wellcome Trust, 2004, p.3) and authors-paymodelscoverabout 40 $\%$ to $60 \%$ according to Regazzi (2004, p.278). The WellcomeTrustreport (2004, p.3) has suggested the separation of the peer-review and the publication processes, applying two differentfees: submissionfee(U \$175) to pay the peer-review costs for all articles, both acceptedand rejected, andan additional publicationfeeto bepaid in casethearticleis accepted.

This model has been much discussed because it can promotejudgements by means notbymerit, favouring thoseinstitutions which can afford to pay.

(iii) Sponsorship or advertising - astudy performed by Kaufman-Will Group (2005, p.8) has shown that over $40 \%$ of the OAjournals do not have their costs covered yet and that they are more dependent on sources of incomesuch as advertising and sponsorship (in kind and financial). As a very important and innovative representation of this type of full OA journals, SciELO* - Scientific Electronic Library Online - is a very sucoessful Brazilian project with theLatinAmerican and Caribbean Centre on Health Sciences Information (BIREME) and itisfunded bytheBrazilian government through afunding agency called FAPESP (TheStateof Sao Paulo Research Foundation). Currently, SciELO Network provide access to high qualified scientific publications, from ten certified collections of online journals from eight countries (Argentina, Brazil, Chile, Colombia, Cuba, Portugal, Spain and Venezuela), and six other certified collections are under development from Costa Rica, Mexico, Paraguay, Peruand Uruguay. SciELOenables open access to over 450 titles and more than 130 thousand onlinefull-text articles in thepublic Health and Social Sciences fields*.

Accordingto Kuramoto(2006), in developingcountries such as Brazil, in which the investments to the development of scientificresearch are limited butits potential is high, the incentive for adopting an open

\footnotetext{
*http:// www.scielo.br

${ }^{* *}$ Source: SciELO website: http:// www.eventos.bvsalud.org/scielo10/ presentation.php?lang=en
} 
access approach should bea compulsory action by the government.

(iv) Subscription to the print version of thejournal represents 28\%ofjournalslistedbyDOAJ (Regazzi, 2004, p.278).

(v) Directorindirectpublicfunding- 55\%of thejournals listedbyDOAJ rely on thismodel (Regazzi, 2004, p.278).

Moreover, the experimentation and adaptations of the traditional business models to deal with thechangesled by OA havebeen thefollowing:

(i) Immediately OA- authorscan post thefinal refereed version accepted by thejournal immediately after this acoeptance(e.g. Elsevier).

(ii) DelayedOA - thisisbased on thesubscription model and refers to the publication of thearticle online free, after a certain period (e.g. J ournal of Biological Chemistry).

(iii) Optional OA - publishers offer theoption of posting the author's article online, on a free way (to the end user) andimmediatelyafter publication, sincetheauthor paysafee.

(iv) OAaccording to population or country or low gross nationalincome.

Results froma surveyperformed by theKaufman-Will Group (2005, pp.13-24) showed that 60\%ofthefull OA journalsplantoadoptortestanewbusinessmodelinthenext threeyears. Also, a report developed by theWellcome Trust(2003, p.20) showed thatpublishersofanysizeand type are in transition to OA models, trailing them by usingoneormore of theirjournals or theentirelist.

\section{(b) The Self-Archiving}

This OA strategy refers to the publishing of research outputsoninstitutional orsubject-basedrepositoriesand also on authors' orinstitutional websites.

Although theaocess to theseresearch outputsisfree, the self-archivingdevelopmentandmaintenanœearenotfree of costs. According to a report of the European Commission (Dewatripont et. al., 2006, p.62), the installation costs for open archives arelowand generally funded by institutions and government funding*.

\footnotetext{
${ }^{*}$ For example, in the UK, the J ISC is funding a series of projects for institutional repositories under the FAIR (Focus on Access to Institutional Resources) Programme, which has created e-print repositories in 20 institutions in the UK.
}

However, it is difficult to plan for themaintenanœeosts becausethey depend* on thenumber of recordsand on thestrategies related to their long-term preservation.

Thefinancialsustainability ofself-archivinghasbeengreatly facilitated by volunteer work, by funding from the higher education institutions and other organisationsand also bypublicfunding.AcoordingtoJ onesetal. (2006, p. 42), auniversity library can fund theinstitutional repository byasking theparentinstitution for funding. Thisstrategy has been facilitated by theannouncements of support for OA research publishing from funding bodies like WellcomeTrust and Research Councils in the United Kingdom(UK), and the possibility of usinga repository for the UK's Research Assessment Exercise 2007-8. Anotherwayisbyfunding theprojectusing thelibrarybudget, which has a greater chance of success acoording to the Jonesetal.(2006, p.42).

In a recent survey, findings showed that the use of IRs has doubled since 2004, the usage for subject-based repositories has increased to almost $60 \%$, and $49 \%$ of therespondents stated that they have self-archived at least onearticle during the last threeyears (Swan \& Brown, 2005). As IRs adoption grows, it complements and at the sametimeit threats the dissemination of the scholarly work made by publishers, because users can graduallymoveto aocess articles by using theIRs, since theyoften accessscientificinformation by theinstitution gatewayand theyrely on librariesindications.

Therefore, theIRs challenge the established revenue streams because they can beused to access scientific content freely, decreasing the usage of the toll-access journals. Acoordingto Crow(2002, p. 24) theopen acoess nature of IRs "threatenstheexistingsubscription-based business models and theattendantrevenuestreams of manyscholarlypublishers".

Similarly, the growing of IRs risks the existing subscription-basedmodel of commencial publishers and of non-profitscholarly societies becauseof thepotential loss of subscribers, which can affect prices and margins. It has been noticeable that the dependence of commercial publishers on thesubscription model is still high, which risks their adoption of alternative ways of revenuegeneration. Waltham (2005) hasobserved that thenumber of institutional subscriptions is decreasing, but publishersstill highlyrely on them.

\footnotetext{
*For example, the DSpace is MIT's IR costs are around \$285,000 per year to maintain ongoing costs for technical maintenance, server spaceand promotion (www.ebrary.com/ corp/ newspdf/ ebrary_EPS Insights_24Nov2005.pdf) [aocessed 18/04/20062:39pm].
} 


\section{Adaptingbusinessmodelstothepotentialof disaggregatingofadivities}

A publishers' subscription-based business model issubstantiallyaffected by thepotential ofdisaggregatingpublishingactivities, because these can be performed by different and separateagents, andalso becausecompetition can beengendered, underminingtraditional publishers' monopolistic bargain power and pricing practices. Crow (2002, p.24) has pointed out that the high price practices allowed by thecurrent integrated valuechain will be "impossible to sustain in a disaggregated, less monopolistic environment".

The functions in scientific communication such asregistration, awareness, archiving* and certification arehighly vertically-integrated (Roosendaal \&Geurts, 1999, pp. 14-20). The first three functions are performed by $\mathrm{OA}$ strategies, and thecertification function gives publishers' respectability and increases their attractiveness, butitisactually performed by academics. Thus, itisnot difficult toempower academics with therightresourcesin orderto enablethem bean independent player and perform thecertification activities. Acoording to a report of European Commission (Dewatripontetal., 2006, p.43):

"Recent evolutions suggest that certification could bedonethrough other meansthanjournal publishing. Itisan open question at this point whether future business models will continue to bundle these two activities [certification and registration], or whether aseparatecertification servicewill emerge, distinctly from dissemination of peer-review".

TheIRsand theoverlay journal (figura3) aresignals of the disaggregation of functionsin thevalue chain (e.g. Biomed as the digital repository for all the fundedresearch publications, and HighWire Press). Overlay journals (Fig.3) arethose which "point to articles and

${ }^{*}$ Functions: registration is the establishing the intellectual priority of an idea, concept, or research; certification is about certifying the quality of the research and/ or the validity of the claimed finding; awareness is ensuring the dissemination and accessibility of research providing a means by which researchers can become aware of new research; and archiving is preserving the intellectual heritage for future use (Crown, 2002, p. 7).
FIGURE3

Examples of the overlayjournals. Thefirst one is theJ ournal PerspedivesinEledtronicPublishing and thelastoneistheJournal ApplicationsofSupenoonductivity.

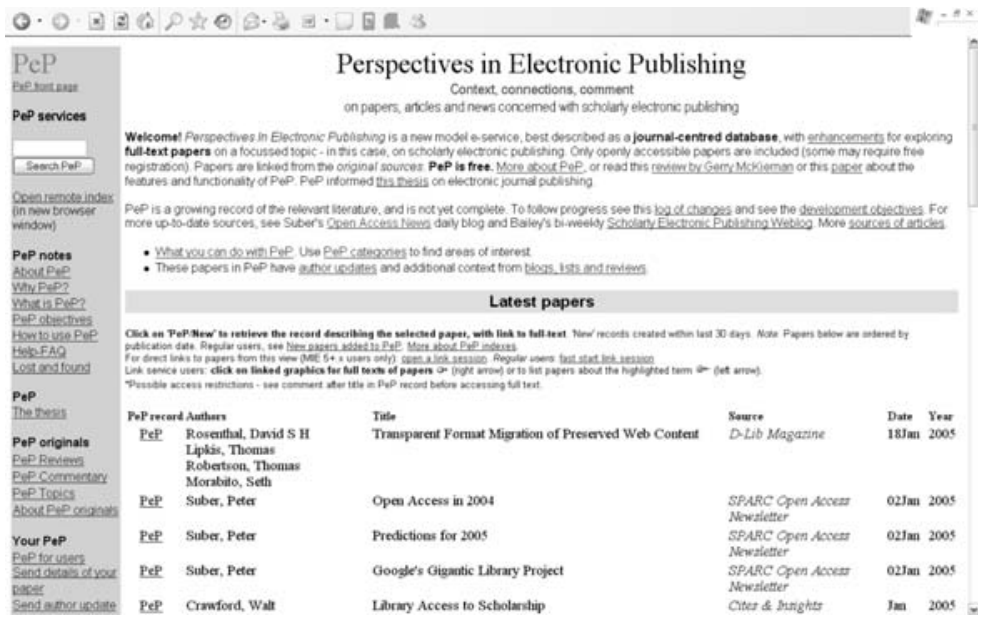

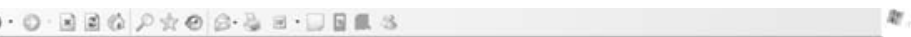
V) Applications of Superconductivity

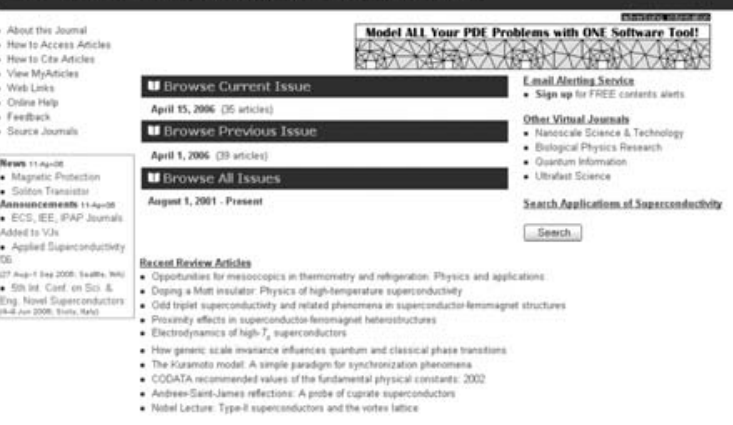

research hosted by oneor morerepositories" and these articles may havebeen publishedin refereedjournals or maybepreprints(Crow, 2002, p.13).

\section{EVOLVINGBUSINESSMODELS}

In the discussion about which business models can evolve, littleinterest for the author or reader facing charges has been evidenced. According to survey performed by Rowlands \& Nicholas (2005, p.38), libraries should not be the largest contributor to the journals costsas they currentlydo. Thepreferred model was that onein which theresearch funders, commercial sponsors and central government are committed with thecharges (in this order) (figura4). 
Thehybridbusinessmodels, which mixes theopen- and toll-acoess is a reality and they will probably co-exist with respectivetrade-offs. In this context, the authors-pay model has being equally controversial as it may risk quality standards of articles publishing, because pressuresmayhappen ifpublishers donot haveenough to publish and pay the bill. Additionally, this model requires a huge cultural changeby authors, which creates barriersforits development.

On theother hand, the Wellcome Trust proposition about adopting separate submission fees (peer-review) and publication fees seems to be reasonable and this proposition minimises the potential disincentive to the model. Additionally, this model isattuned to the disaggregatingnature ofe-publishingand $\mathrm{OA}$, and also attuned to thenatural movement in this industry (even in long-term). The unbundling of the certification and dissemination functions can be operationalised by the repositoriesand thebrowsing/ searching services, and the peer-review process can be performed by an independentacademicagent.

Equally probableis thegrowing of theadoption of IRs, considering the concretization of strong support from funding agencies, research institutions, rewarding systems, librarians, thechangesin researchers' publishing practices and the clear institutional policies regarding thisissue. IRs will beprobablyincreasein use, and thus, developingthebroad mass of OA researcharticles which is required to give consistency to the most effective business and operational models. Promoting this grow are also the external movements like the European Commission (2006, p.87) 'A1' recommendations (seein appendix 1). IRs will not substitutethe commercial publishing. Both will co-exist and the value delivery from both should go beyond the content access and should support users in navigating through the best quality scientificinformation.

Whatever themodel thatevolves, a hugecultural change in authors' and institutions publishing practices will be required in order to maketheopen acoess happen and to consolidatetherightbusinessmodels for thetraditional publishers. Someexternal changes should also happen in order to sustain the wholechangingscenario, such as policies, rewardingsystemsandinstitutionsmandates.
All the stakeholders should be highly flexible and adaptableand, on top of that, they should be partners because the changes affect the whole scholarly publishingsystem. Theevolvingbusiness model will primefor themost effective way that sciencedeserves to be communicated to society and for financial, operational and strategic sustainability.

Artigo submetido em 21/03/2007eaceito em 19/ 10/2007.

\section{REFERENCES}

BOSC, H.; HARNAD, S. In a paperless world a newrole for academic libraries: providingOA. Learned Publishing, v. 18, n. 2, p. 95-100, 2005.

CHUANG, J . C.; SIRBU, M. Networld delivery of information goods: optimal pricing or articles and subscriptions. In: KAHIN, B., VARIAN, H. R. (Ed.). Internet publishing and beyond: the economics of digital information and intellectual property. Cambridge, Mass: MT Press, 2000. p.138-166.

CLARKE, R. Open source software and open content as models for eBusiness. In: INTERNATIONAL ECOMMERCE CONFERENCE, 17., 2004, Slovenia. Electronic proceedings...Disponível em: <http:// www.anu.edu/people/ Roger.Clarke/ EC/ Bled04.html>. Aoesso em: mar. 2006.

COX, J . Evolution or revolution in scholarly publishing. In: GORMAN, G. E; ROWLAND, F. (Ed.). International yearbook of library and informationmanagement2004/2005: scholarlypublishinginanElectronic Era. London: Facet Publishing, 2004. p. 54-74.

CROW, R. The casefor institutional repositories: a SPARCposition paper: the Scholarly Publishing \&Academic Resources Coalition: release 1.0. 2002. Disponível em: <http:// www.arl.org/ sparc/IR/ ir.html>. Acesso em: mar. 2006. 
DEWATRIPONT, M. et.al. Study on theeconomicand technical evolution of thescientificpublication marketsin Europe. [S.l.]: European Commission. 2006. Disponível em: <europa.eu.int/ comm/research/science-society/ pdf/scientific-publication-study_en.pdf $>$. Acesso em: mar. 2006.

GADD, E.; OPPENHEIM, C; PROBETS, S. RoMEO studies 1: the impact of copyright ownership on academic author self-archiving. J ournal ofDocumentation, v. 59, n. 3, p. 243-277, 2003.

HARNAD, S. On maximizing journal articleaccess, usageand impact. [S.l.]: Haworth Press, 2005. Disponível em: <http:// eprints.ecs.soton.ac.uk/ 10793/ >. Acesso em: mar. 2006.

HOORN, E. Towardsgoodpractices of copyrightinopen acossjournals: a study among authors of articles in open access journals. [S.l.]: University of Groningen, 2005. Disponível em: <www.surf.nl/download/ Towards\%20Good\%20Practices\%20of\%20Copyright\%20in\%20Open\%20 Access\%20J ournals.pdf>. Acesso em: mar. 2006.

HOUGHTON, J. W. Economics of publishing and the future of scholarly communication. In: GORMAN, G. E; ROWLAND, F. (Ed.). Internationalyearbookoflibraryandinformationmanagement2004/2005: scholary publishing in an Electronic Era. London: Facet Publishing, 2004.p.164-88.

; STEELE, C.; HENTY, M. Research practices and scholarlyoommunicationin thedigital environment. Learned Publishing, v. 17, n. 3, p. 231-249, 2004.

JOHNSON, R. K. Thefutureofscholarly oommunicationin thehumanities: adaptation or transformation?: SPARC (Scholarly Publishing \& Academic Resources Coalition). [S.l.: s.n.], 2004. Paper delivered at a program entitled "Scholarly J ournals: Our Futures in the Digital Soup", presented by the Council of Editors of Learned J ournals on December 30, 2004 in conjunction with the Modern Language Association Annual Convention.

JONES, R.; ANDREW, T.; MACCOLL, J . Theinstitutional repository. Oxford, England: Chandos Publishing, 2006.

KAUFMAN-WILL GROUP; LLC. The facts about OA: a study of the financial and nonfinancial effects of alternative business models on scholarly journals. [S.l.]: Association of Learned and Professional Society Publishers, 2005. p. 1-121. Disponível em: <http:// www.alpsp.org/ publications/FAOAcompleteREV.pdf>. Acesso em: mar. 2006.

KURAMOTO, H. Informação científica: proposta deum novo modelo para o Brasil. Ciência da Informação, Brasília, v. 35, n. 2, p. 91-102, 2006.

LUSTRIA, M. L. A.; CASE, D. O. The SPARC initiative: a survey of participants and features analysis of their journals. The J ournal of AcademicLibrarianship, v. 31, n. 3, p. 236-246, 2005.

MACKIE-MASON, J . K.; RIVEROS, J . F. Economics and electronic access to scholarly information. In: KAHIN, B.; VARIAN, H. R. (Ed.). Internetpublishing and beyond: theeconomics of digital information and intellectual property. Cambridge, Mass: MIT Press, 2000. p. 203229. et al. A report on the PEAK experiment: usage and economic behavior. D-LibMagazine, v. 5, n. 7/ 8, 1999. Disponível em: <http:/ / www.dlib.org/ dlib/july99/ mackie-mason/ 07mackiemason.html>. Acesso em: mar. 2006.

PORTER, M. E.; MILLAR, V. E. Howinformation givesyou competitive advantage. Harvard Business Review, v. 63, n. 4, p. 149-160, 1985.

REGAZZI, J . The shiftingsands of open access publishing: apublisher's view. SerialsReview, v. 30, n. 4, p. 275-280, 2004.

ROOSENDAAL, H. E.; GEURTS, P. A. Th. M. Forces and functions in scientificcommunication: an analysis of theirinterplay. 1999. Disponível em: <http:// www.ub.utwente.nl/ webdocs/ dinkel/ 1/ 00000001.pdf>. Acesso em: mar. 2006.

ROWLANDS, I.; NICHOLAS, D. The changing scholarly communication landscape: an international survey of senior researchers. Learned Publishing, v. 19, n. 1, p. 31-55, 2006.

.Newjournal publishingmodels: aninternational survey of senior researchers: a CIBER report for the Publishers Association and the International Association of STM Publishers. [S.l.: s.n.], 2005. p. 1-75.

SWAN, A.; BROWN, S. J ISC/ OSI journal authors survey report. In: J ISC report, 2004. Disponível em: <http:// www.jisc.ac.uk/ uploaded_documents/J ISCOAreport1.pdf $>$. Acesso em: mar. 2006.

OAself-archiving: an authorstudy. 2005.J ISCTechnical Report. Disponível em: <http:/ / eprints.ecs.soton.ac.uk/ 10999/ >. Acesso em: mar. 2006.

TENOPIR, C. Useand users of electroniclibrary resources: an overview andanalysis of recentresearchstudies. Washington: Council on Library and Information Resources Washington. 2003. Disponível em: «http:/ / www.clir.org/ pubs/abstract/ pub120abst.html>. Acesso em: 2 abr. 2006.

THEWELCOMETRUST. Costsand businessmodelsinscientificresearch publishing: a report commissioned by the Wellcome Trust. 2004. Disponivel em: বhttp:// www.welloome.ac.uk/ doc WTD003181.html>. Acessoem: mar. 2006.Thedevelopment ofe-publishingand thechanges in scholarly communication and publishing chain $\mathbf{1 7}$

VANDE SOMPEL, H. etal. Rethinking scholarly communication. DLib Magazine, v. 10, n. 9, 200-. Disponível em: 〈http:/ / www.dlib.org/ $\mathrm{dlib} /$ september04/vandesompel/09vandesompel.html>. Acesso em: mar.2006.

WALTHAM, M. Challengesto theroleof publishers. Learned Publishing, v. 16, p. 7-14, 2003.

.J ISC: learned society open access business models. In: J ISCreport. [S.l.: s.n.], 2005. Disponível em: <http:// www.jisc.ac.uk/ uploaded documents/Learned\%20 Society\%200pen $\%$ 20Access\%20Business\%20Models.doc>. Acesso em: mar. 2006. 